https://jurnal.uns.ac.id/jdc

\title{
Peningkatan Hasil Belajar Matematika Kelas VI SDN Jumputrejo Melalui Metode Blanded Lerning dengan Aplikasi Whatsapp
}

\section{Machfud}

SDN Jumputrejo

machfud@gmail.com

\author{
Sejarah Artikel \\ diterima 15/07/2019
}

\begin{abstract}
Evaluation of learning outcomes turns out to be quite disappointing. There are 23 out of 28 students or $78.5 \%$ failed the mastery learning. To overcome these problems, the teacher tries to use the blended learning method with the WhatsApp group application. The research aims to describe the application of the blended learning method with the WhatsApp application. It uses an action research model carried out at SDN Jumputrejo in second semester in the academic year 2016/2017 in mathematics subject of matter fractions. The results shows that the use of blended learning with WhatsApp group application increases student learning outcomes from $36 \%$ in the pre-cycle to $57.14 \%$ in first cycle and $85.7 \%$ in second cycle. The use of the blended learning method with WhatsApp group application also allows students to study and discuss longer without being bound by time and space

Keywords: mathematics learning outcomes, blended learning
\end{abstract}

\begin{abstract}
Abstrak
Evaluasi hasil belajar ternyata hasilnya cukup mengecewakan, ada 23 siswa dari 28 siswa belumtuntas belajar atau $78,5 \%$ siswa belum tuntas belajar. Untuk mengatasi permasalahan tersebut guru mencoba untuk menggunakan metode blended learning dengan aplikasi whatsapp group. Tujuan dari penelitian ini yaitu mendeskripsikan penerapan metode blanded learning dengan aplikasi whatsapp. Penelitian ini menggunakan model penelitian tindakan dilaksanakan di SDN Jumputrejo pada semester 2 tahun pelajaran 2016/2017 pada mata pelajaran matematika materi pecahan. Berdasarkan hasil penelitian didapatkan data bahwa penggunaan blended learning dengan aplikasi whatsapp group dapat meningkatkan hasil belajar siswadari $36 \%$ pada pra siklus menjadi $57,14 \%$ pada siklus 1 dan $85,7 \%$ pada siklus 2 . Penggunaan metode blended learning dengan aplikasi whatsapp group juga memungkinkan siswa untuk belajar dan berdiskusi lebih lama tanpa terikat ruang dan waktu
\end{abstract} Kata Kunci : hasil belajar matematika, blended learning 


\section{PENDAHULUAN}

Matematika adalah pelajaran utama yang materinya harus benarbenar dikuasai oleh siswa.karena matematika adalah salah satu pelajaran yang diujikan dalam ujian sekolah utama skala Propinsi. Guru kelas VI berharap seluruh siswanya mampu menyelesaikan soal dengan baik dan mampu menguasai seluruh materi yang ada, karena pada hakikatnya materi kelas VI adalah pengulangan dari kelas III sampai kelas VI.

Pembelajaran Matematika tidak lagi mengutamakan pada penyerapan melalui pencapaian informasi, tetapi lebih mengutamakan pada pengembangan kemampuan dan pemrosesan informasi. Untuk ituaktivitas peserta didik perlu ditingkatkan melalui latihan-latihan atau tugas matematika dengan bekerja kelompok kecil dan menjelaskan ide-ide kepada orang lain. (Hartoyo, 2000:24). Jumlah siswa kelas $\mathrm{VI}$ tahun pelajaran 2016/ 2017 adalah 28 dengan 13 siswa laki-laki dan 15 siswa perempuan. Berdasarkan data dokumentasi yang diperoleh dari sekolah yang membandingkan jumlah yang tidak terlalu banyak dibandingkan tahun sebelumnya yang mencapai 31 anak.

Pada pertemuan pertama materi pecahan kelas terlihat biasabiasa saja, seluruh siswanya dapat mengikuti kegiatan pembelajaran dengan tertib.Pada pertemuan ini kegiatan pembelajaran hanya diisi dengan guru menjelaskan dan siswa mendengarkan. Karena hanya mengulang saja, maka guru hanya mengulas sedikit pokok bahasan dan lebih menitik beratkan pada latihan soal.
Pada akhir pembelajaran, seperti biasa guru memberikan evaluasi untuk mengukur tingkat ketercapaian tujuan pembelajaran dan untuk mengukur kemampuan siswa dalam menguasai materi yang diajarkan. Setelah diketahi hasil evaluasi pada pertemuan pertama, ternyata hasilnya sangat mengecewakan.Dari 28 siswa yang mendapat niali di atas KKM hanya 5 siswa atau sebesar 17, 86\%. Hasil tersebut jauh dari harapan guru.

Matematika memang membutuhkan banyak waktu apalagi pada materi yang mengarah pada kegiatan prosedural dan pemecahan masalah.Kedua hal tersebut membutuhkan banyak waktu karena membutuhkan banyak langkahlangkah yang harus dilalui. Setelah melalui perenungan yang mendalam dan diskusi dengan teman sejawat penulis sebagai guru kelas 6 menduga bahwa hal tersebut disebabkan oleh kurangnya pendampingan guru dalam mengerjakan soal.

Sebagai pendidik masa depan, sudah sepatutnya seorang pendidik mampu memanfaatkan fasilitas yang tersedia dan berusaha mengubah potensi negatif menjadi positif dalam kegiatan pembelajaran. Potens iinilah yang dapat ditemukan dalam media sosial yang sudah menjamur bahkan mempengaruhi pola pikir masyarakat dewasa ini. Salah satu contoh media sosial yang sudah cukup dikenal bahkan hampir seluruh masyarakat telah menggunakannya adalah aplikasi WhatsApp.

Pengguna WA menduduki peringkat teratas disbanding dengan aplikasi media sosial.Bertambahnya 
jumlah pengguna ini tidak lepas dari mudahnya menunduh aplikasi dari Google Store maupun semakin banyaknya pengguna smartphone didunia terutama yang berjenis android.

Besarnya potensi WA tersebut, akan tetapi, masih belum terserap dan terpelajari dengan baik dalam dunia pendidikan khususnya di SD. Masyarakat pendidikan di SD masih belum mengeksplorasi dan berinteraksi dengan teknologi komunikasi terutama social media dalam kegiatan pembelajaran Blended Learning, bisa juga
disebut
dengan
Learning, sesuai dengan namanya merupakan suatu metode pembelajaran yang mengkombinasikan metode pembelajaran tatap muka dengan online learning. WhatsApp group discussion memungkinkan untuk dilakukan pembelajaran online karena didalamnya dapat dilakukan interaksi antara guru dengan siswa dan siswa dengan siswa. Melalui WhatsApp group discussion akan memudahkan proses pendampingan kapan saja dan dimana saja.

\section{METODE}

Penelitian ini menggunakan model penelitian tindakan dari Kemmis dan Taggart (dalam Arikunto, Suharsimi, 2002:83), yaitu berbentuk spiral dari siklus yang satu kesiklus yang berikutnya. Setiap siklus meliputi planning (rencana), action (tindakan), observasi (pengamatan) danreflection (refleksi). Langkah pada siklus berikutnya adalah perencanaan yang sudah direvisi tindakan, pengamatan dan refleksi. Sebelum masuk padasiklus I dilakukan tindakan pendahuluan yang berupa identifikasi permasalahan.

Pada tahap perencanaan, peneliti melakukan studi pendahuluan (study case). Studi pendahuluan tersebut menghasilkan masalahmasalah proses dan hasil pembelajaran matematika materi pecahan siswa kelas VI SDN Jumputrejo Sukodono Sidoarjo. Pada tahap Pelaksanaan peneliti mempraktikkan pembelajaran sesuai dengan desain pembelajaran (RPP) yang telah disusun sebagaimana terlampir, merekam berbagai peristiwa pembelajaran dan mendokumentasikan hasil-hasil tes formatif siswa. Evaluasi/Observasi dilakukan untuk mengetahui sejauh mana keberhasilan pembelajaran setelah dilakukan tindakan perbaikan. Refleksi yang dimaksud adalah melakukan analisa ulang terhadap apa yang sudah dikerjakan, apa yang belum dikerjakan, apa yang belum dan telah tercapai, masalah apakah yang belum terpecahkan dan menentukan tindakan apa lagi yang perlu dilakukan untuk meningkatkan kualitas proses dan hasil pembelajaran, yang akan dilanjutkan pada siklus berikutnya

Penelitian tindakan kelas ini dilaksanakan di SDN Jumputrejo pada semester 2 tahun pelajaran 
2016/2017 pada mata pelajaran matematika materi pecahan.Subjek penelitian adalah siswa kelas VI yang berjumlah 28 anak. Data-data yang diperlukan dalam penelitian ini diperoleh melalui observasi pengolahan pembelajaran dengan metode blended learning dan tes formatif buatan guru pada akhir pembelajaran.

Istilah blended learning pada awalnya digunakan untuk menggambarkan pembelajaran yang menggabungkan tatap muka dengan pembelajaran online. Saat ini istilah blended menjadi populer, maka semakin banyak kombinasi yang dirujuk sebagai blended learning.Blended learning dapat menggabungkan pembelajaran tatap muka (face-to-face) dengan pembelajaran berbasis komputer. Artinya, pembelajaran dengan pendekatan pembelajaran tatap muka dan pembelajaran melalui media komputer, telpon seluler atau iPhone, saluran televisi satelit, konferensi video, dan media elektronik lainnya. Pebelajar dan pengajar/fasilitator bekerja sama untuk meningkatkan kualitas pembelajaran

\section{Gambar 1. Konsep Blended Learning}

(Sumber :http:// orangecharterschool.org/the-future -of-learning-has-arrived-atocs/)

belajar mandiri, berkelanjutan, dan

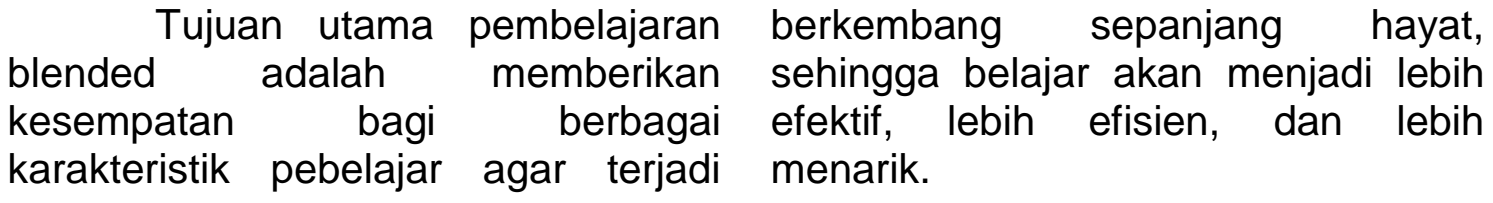

\section{PEMBAHASAN}

Berdasarkan hasil analisi data pada siklus kedua diperoleh kesimpulan sebagai berikut :

- Dari 28 siswa yang mencapai ketuntasan belajar sebanyak 24 siswaatau ketuntasan kelas sebesar $85,7 \%$
- Rata- rata kelas adalah 86,1

- Tidak diperlukan siklus III karena kelas sudah tuntas belajar 
Tabel1. Perbandingan Antar Siklus

\begin{tabular}{llccc}
\hline \multicolumn{1}{c}{ Hasil } & Pra & Siklus & Siklus \\
Pengamatan & Siklus & $\mathbf{1}$ & $\mathbf{2}$ \\
\hline 1 & $\begin{array}{l}\text { Rata-rata } \\
\text { kelas }\end{array}$ & 69,28 & 77,4 & 86,1 \\
2 & $\begin{array}{l}\text { Siswa yang } \\
\text { tuntas belajar }\end{array}$ & 10 & 16 & 24 \\
3 & $\begin{array}{l}\text { Persentase } \\
\text { ketuntasan }\end{array}$ & $36 \%$ & 57,14 & $\begin{array}{c}85,7 \\
\%\end{array}$ \\
\hline
\end{tabular}

Hasil penelitain ini merupakan analisis data yang diperoleh dari kegiatan observasi berupa pengamatan pengelolaan pembelajaran menggunakan metode blended learning dan data tes formatif siswa pada setiap siklus.

Hasil observasi pada siklus pertama dapat dijelaskan bahwa kegiatan pembelajaran berjalan sesuai dengan rencana pelaksanaan pembelajaran (RPP). Ketika guru menanyakan tugas dirumah yang telah dikirim secara on line seluruh siswa telah mengerajannya dengan baik. Meskipun setelah dibahas ada 10 siswa yang mendapat nilai dibawah KKM, 18 siswa yang lain telah mampu menjawab soal dengan baik. Aktivitas siswa juga terlihat sangat bagus, karena tidak ada siswa yang diam saat diskusi kelompok hanya saja ketika presentasi ada yang masih malu-malu dalam menjelaskan jawaban soal.

Respon siswa terhadap stimulus yang diberikan oleh guru juga bagus, itu terbukti dari beberapa lontaran pertanyaan guru dapat dijawab dengan baik oleh beberapa siswa di kelas. Guru cukup lugas dalam menjelaskan pokok-pokok bahasan materi. Ketika ada siswa yang tidak mampu mempresentasikan hasil diskusi kelompok dengan baik guru juga bijaksana dalam menyikapinya. Guru juga selalu memberikan motivasi bagi siswa yang malu-malu dalam kegiatan presentasi.

Dalam penelitian ini cara yang digunakan untuk memberikan umpan balik adalah dengan memberikan kuis secara online. Pada akhir pembelajaran dijadwalkan bahwa pada pukul 19.00-20.00 akan diadakan kuis. Selain kuis melaui WA Group siswa dapat melakukan diskusi secara online, kapanpun dan dimanapun mereka berada.

Metode blended learning memungkinkan terjadinya kelas 24 jam. Artinya pembelajaran tidak terikat ruang dan waktu. Siswa bisa bertanya kapanpun mereka merasa kesulitan. Fasilitas umum sekarang ini telah memiliki fasilitas wifi yang bisa digunakan oleh sispapun, salah satunya adalah di balai desa. Begitu juga dengan siswa-siswi di SDN Jumputrejo. Mereka sering menggunakan fasilitas itu untuk mendapat akses internet gratis.

Berdasarkan data pada siklus pertama diperoleh kesimpulan sebagai berikut :

Dari 28 siswa dalamsatukelas, yang telahmemperoleh 
ketuntasan belajar sebanyak 16 siswa atau ketuntasan kelas sebesar $57,14 \%$

- Rata- rata kelas adalah 71,72

- Diperlukan siklus kedua untuk menuntaskan belajar siswa

Hasil observasipada siklus 2 didapat data bahwa kegiatan pembelajaran berjalan sangat lancar dan menyenangkan. itu terbukti dengan antusiasme siswa dalam kegiatan pembahasan kuis. Mereka juga merasa senang mendapatkan hadiah karena telah mampu menjawab kuis dengan benar.

Guru telah menyampaikan seluruh tahapan dalam RPP mulai dari penyampaian tujuan pembelajaran, penyampaian pokokpokok materi, membentuk kelompok, kegiatan diskusi, pembahasan soal sampai dengan kegiatan evaluasi. Guru juga memberikan motivasi dan pendampingan bagi siswa yang tidak mampu mengerjakan soal.

\section{SIMPULAN}

Penggunaan metode blended learning memungkinkan siswa untuk belajar dan berdiskusi lebih lama tanpa terikat ruang dan waktu Metode blended learning terbukti dapat meningkatkan hasil belajar siswa dan meningkatkan nilai rata-rata kelas. Penggunaan metode blended learning dapat meningkatkan aktivitas belajar siswa.

Saran Berdasarkan hasil penelitian yang telah dilakukan didapatkan beberapa saran diantaranya yaitu: Dalam menerapkan model pembelajaran hendaknya peneliti selanjutnya menyesuaikan dengan karakteristik siswa dan karakteristik materi.Dalam menerapkan model pembelajaran blanded learning hendaknya peneliti selanjutnya mengalokasikan waktu semaksimal mungkin, sehingga langkah-langkah dalam model dapat dilakukan secara utuh. Dalam menerapkan model pembelajaran blanded learning hendaknya guru memahami dengan betul tahapan model.

\section{DAFTAR PUSTAKA}

Arikunto, Suharsimi. 2003. Prosedur Penelitian, Suatu Praktek. Jakarta: Bina Aksara.

Hartoyo. Dasar-dasar. 2000. Interaksi Belajar Mengajar. Surabaya Usaha Nasional.

http://orangecharterschool.org/thefuture -of-learning-has-arrived-atocs/
Prayitno, W. (2015). Implementasi Blended Learning Dalam Pembelajaran Pada Pendidikan Dasar dan Menengah. Jurnal Pendidikan, 6(01).

Thorne, Kaye. 2003. Blended Learning: How to integrate online \&traditional learning. London: Kagan Page Limited. 
Wicaksono, V. D., \& Rachmadyanti, P. (2017). Pembelajaran blended learning melalui google classroom di sekolah dasar. 